\title{
Fusidic acid resistance among staphylococci strains isolated from clinical specimens in a general hospital
}

\author{
Bir devlet hastanesindeki klinik örneklerden izole edilen stafilokok suşlarında fusidik asit direnci
}

\author{
Türkan Toka Özer ${ }^{1}$, Erkan Yula $^{2}$, Alicem Tekin ${ }^{3}$, Özcan Deveci ${ }^{4}$ \\ ${ }^{1}$ Klzlltepe General Hospital, Department of Medical Microbiology, Mardin, Turkey \\ ${ }^{2}$ Mustafa Kemal University, Medical Faculty, Department of Medical Microbiology, Hatay, Turkey \\ ${ }^{3}$ Dicle University, Medical Faculty, Department of Medical Microbiology, Diyarbakır, Turkey \\ ${ }^{4}$ Dicle University, Medical Faculty, Department of Infectious Diseases, Diyarbakır, Turkey
}

Geliş Tarihi / Received: 22.08.2011, Kabul Tarihi / Accepted: 01.12.2011

\section{ABSTRACT}

Objectives: The aim of this study was to investigate in vitro susceptibility of fusidic acid to clinic isolates of staphylococci.

Materials and methods: The forty-one coagulase negative staphylococci (CNS) and 18 Staphylococcus aureus strains isolated from various clinical specimens were included in this study. Staphylococci isolates were identified by conventional methods such as colony morphology onto medium, gram staining, catalase and coagulase tests. According to "Clinical and Laboratory Standards Institute (CLSI)" criteria, antimicrobial susceptibility testing of isolates was performed by Kirby-Bauer's disk diffusion method.

Results: The seventy-two percent of the isolated S.aureus were defined as methicillin sensitive-S.aureus (MSSA), $28 \%$ of the isolated S.aureus were defined as methicillin resistant-S.aureus (MRSA). The difference among fusidic acid susceptibility rates of MSSA and MRSA strains was not statistically significant $(p=0.305)$. The twenty-nine percent of the isolated CNS were defined as methicillin sensitive-CNS (MS-CNS), $71 \%$ of the isolated CNS were defined as methicillin resistant-CNS (MR-CNS). There was no statistically significant difference between MS-CNS and MR-CNS strains for fusidic acid susceptibility rates $(p=0.490)$. But the difference among fusidic acid susceptibility rates of CNS and S.aureus strains was statistically significant $(p<0.001)$. CNS strains were found more resistance than S.aureus strains for fusidic acid.

Conclusion: In this study, the resistance rates were detected to increase for fusidic acid along with methicillin resistance. Among CNS isolates, fusidic acid resistance rates were significantly more elevated than that for S.aureus. Fusidic acid remains as an alternative in the treatment of infections due to staphylococci.

Key words: Staphylococcus aureus, fusidic acid, microbial sensitivity test

\section{ÖZET}

Amaç: Bu çalışmanın amacı, klinik örneklerden izole edilen stafilokok suşlarında fusidik asidin in vitro etkinliğinin araştırılmasıdır.

Gereç ve yöntem: Çalışmaya çeşitli klinik örneklerden izole edilen 41 koagülaz negatif stafilokok (KNS) izolatı ile 18 Staphylococcus aureus suşu dahil edildi. Stafilokok izolatları besiyeri yüzeyindeki koloni morfolojisi, gram boyama, katalaz ve koagülaz testleri gibi konvansiyonel yöntemlerle identifiye edildi. İzolatların antimikrobiyal duyarlılıkları "Clinical and Laboratory Standards Institute (CLSI)" önerileri doğrultusunda Kirby-Bauer disk difüzyon yöntemi kullanılarak çalışıldı.

Bulgular: İzole edilen S.aureus suşlarının \% 72'si metisiline duyarlı (MSSA), \% 28'i metisiline dirençli (MRSA) olarak tanımlandı. MSSA ve MRSA suşlarının fusidik asit duyarlılık oranları arasındaki fark istatistiksel olarak anlamlı bulunmadı ( $p=0.305)$. İzole edilen KNS'lerin \% 29'u metisiline duyarlı (MS-KNS), \% 71'i metisiline dirençli (MRKNS) olarak tanımlandı. MR-KNS ve MS-KNS suşlarının fusidik asit duyarlılık oranları arasında istatistiksel olarak anlamlı fark yoktu $(p=0.490)$. Ancak, KNS ve S.aureus suşlarının fusidik asit duyarlııı oranları arasındaki fark istatistiksel olarak anlamlıydı $(p<0.001)$. KNS suşları fusidik aside S.aureus suşlarından daha fazla dirençli bulundu.

Sonuç: Bu çalışmada, metisilin direnci ile birlikte fusidik aside karşı da direnç gelişiminde artış olduğu gözlendi. KNS izolatları arasındaki fusidik aside direnç oranları S.aureus suşlarına göre önemli ölçüde artmıştır. Sonuç olarak, fusidik asit stafilokoklara bağlı enfeksiyonların tedavisinde hala bir alternatif olarak durmaktadır.

Anahtar kelimeler: Staphylococcus aureus, fusidik asit, mikrobiyal duyarlılık testi 


\section{INTRODUCTION}

Fusidic acid is an antimicrobial drug obtinated from Fusidium coccineum. ${ }^{1}$ Since being made available for clinical use in 1960s, fusidic acid has been utilized in Europe and Australia for the treatment of staphylococcal infections. During the early development of this antimicrobial drug, resistance appeared to be selected easily in vivo and in vitro; but data from countries where fusidic acid was used in logical quantities showed that resistance rates stayed modest and that staphylococci showing elevated fusidic acid minimum inhibitory concentration (MIC) values hadn't emerged rapidly. ${ }^{2}$

Fusidic acid inhibits protein synthesis by blocking the elongation of the nascent polypeptide chain through binding to EFG on the ribosome and preventing the dissociation of EFG-GDP from the ribosome. ${ }^{3,4}$ The rate of fusidic acid resistance isn't very high; but the existence of clinical staphylococcal species that are resistant to fusidic acid has been reported. ${ }^{5}$

In present study, in vitro susceptibilities of a variety of staphylococci strains isolated from clinical specimens to fusidic acid were investigated.

\section{MATERIALS AND METHODS}

\section{Bacterial isolates}

From April 2009 to August 2011, 41 coagulase negative staphylococci (CNS) and 18 coagulase positive S.aureus strains isolated from various clinical specimens that had been sent to microbiology laboratory of Kiziltepe General Hospital had been included in this study. S.aureus ATCC 29213 has consistently been used as a quality control strain. 5\% sheep blood agar (Oxoid Ltd., Basingstoke, UK) medium was used for bacterial growth at $35 \pm 2^{\circ} \mathrm{C}$ with aeration for 18-24 hours. Mueller-Hinton agar (Oxoid Ltd., Basingstoke, UK) medium was used for all determinations of Kirby-Bauer's disk diffusion method. All isolates were identified by conventional methods such as colony morphology onto medium, gram staining, catalase and coagulase reactions.

\section{Antimicrobial susceptibility testing}

Methicillin resistance was determined by incubation of oxacillin $(1 \mu \mathrm{g})$ disk onto Mueller-Hinton agar medium aerobically at $35 \pm 2{ }^{\circ} \mathrm{C}$ for 18 - 24 hours. Oxacillin inhibition zone diameter $>13 \mathrm{~mm}$ were evaluated as susceptible, $<10 \mathrm{~mm}$ were resistant. Antimicrobial susceptibility testing was performed by Kirby-Bauer's disk diffusion method in accordance with the recommendations of CLSI. ${ }^{6}$

For fusidic acid, where CLSI does not provide disk susceptibility breakpoints, the required diameters for sensitivity and resistance were $\geq 22 \mathrm{~mm}$ and $<22 \mathrm{~mm}$, respectively (10 $\mu \mathrm{g}$ fusidic acid disk) according to the European Committee on Antimicrobial Susceptibility Testing (EUCAST) clinical breakpoints. ${ }^{7}$ However, in this study fusidic acid susceptibility was detected according to the criteria of Comite de L'antibiogramme de la Societe Française de Microbiologie, and inhibition zone of $\geq 22$ $\mathrm{mm}$ was considered as sensitive, $16-21 \mathrm{~mm}$ as intermediate, $\leq 15 \mathrm{~mm}$ as resistant.

\section{Statistical analysis}

Data of this study were analyzed by Epi InfoTM 7-Community Edition (Centers for Diseases Control and Prevention, Atlanta, GA, USA) statistical package program. Statistical evaluation of difference between MR-CNS and MS-CNS strains, between MSSA and MRSA strains, between CNS and S.aureus strains for fusidic acid susceptibility was performed with the Fisher's Exact test. The p value of $<0.05$ was selected for statistical significance.

\section{RESULTS}

The eighty-nine percent of S.aureus strains and 39\% of CNS strains were found as sensitive to fusidic acid. Fusidic acid susceptibility rates of staphylococci strains were shown on Table 1 . The difference among fusidic acid susceptibility rates of CNS and S.aureus strains was statistically significant $(\mathrm{p}<0.001)$. CNS strains were found more resistance than S.aureus strains for fusidic acid.

The seventy-two percent of the isolated S.aureus were defined as MSSA, $28 \%$ of the isolated S.aureus were defined as MRSA. Resistance to fusidic acid was observed in $20 \%$ ( 1 of 5) of MRSA isolates and $8 \%$ ( 1 of 13 ) of MSSA. The difference among fusidic acid susceptibility rates of MSSA and MRSA strains was not statistically significant $(p=0.305)$ (Table 2). 
The twenty-nine percent of the isolated CNS were defined as MS-CNS, $71 \%$ of the isolated CNS were defined as MR-CNS. While $45 \%$ of MR-CNS was resistant to fusidic acid, fusidic acid resistance was found to be $25 \%$ in MS-CNS. There was no statistically significant difference between MS-CNS and MR-CNS strains for fusidic acid susceptibility rates $(\mathrm{p}=0.490)$ (Table 3$)$.

Table 1. Fusidic acid susceptibility rates of staphylococci strains.

\begin{tabular}{llll}
\hline Bacteria & S n (\%) & R n (\%) & $p$ \\
\hline S.aureus $(n=18)$ & $16(89)$ & $2(11)$ & $<0.001$ \\
CNS $(n=41)$ & $16(39)$ & $25(61)$ & \\
\hline
\end{tabular}

S: sensitive; R: resistant

Table 2. Fusidic acid susceptibility rates of CNS strains.

\begin{tabular}{lllll}
\hline Bacteria & & $S n(\%)$ & $R n(\%)$ & $p$ \\
\hline CNS (n=41) & MS-CNS (n=12) & $3(25)$ & $9(75)$ & 0.305 \\
& MR-CNS (n=29) & $13(45)$ & $16(55)$ & \\
\hline
\end{tabular}

S: sensitive; R: resistant

Table 3. Fusidic acid susceptibility rates of S.aureus strains.

\begin{tabular}{lllll}
\hline Bacteria & & S n (\%) & R n (\%) & $p$ \\
\hline S.aureus $(n=18)$ & MSSA $(n=13)$ & $12(92)$ & $1(8)$ & 0.490 \\
& MRSA $(n=5)$ & $4(80)$ & $1(20)$ & \\
\hline
\end{tabular}

S: sensitive; R: resistant

\section{DISCUSSION}

Fusidic acid is used in European Countries and Australia for a long time. It has also been used in other countries, except in the United States in recent years. Fusidic acid resistance has developed slowly, and the level of resistance and genetic mechanisms responsible generally reflect the time since introduction, indications for treatment, administration route, and prescribing practices widely throughout the world. ${ }^{8}$

Fusidic acid resistance has increased among S.aureus strains, including MRSA in the past twenty years. But, there are limited data concerning the relative importance in this process of the different staphylococcal determining factors that mediate resistance to fusidic acid. Moreover, the roles played by clonal dissemination of fusidic acid-resistant strains versus horizontal transmission of fusidic acid resistance determining factors have not been examined in detail. ${ }^{9}$

Previous studies related with fusidic acid resistance in strains isolated from clinical specimens have mainly focused on MSSA and other staphylococci. ${ }^{5}$ Chen et al. recently reported that the prevalence of fusidic acid-resistance determinants was quite different between MRSA and MSSA groups. ${ }^{10}$

In spite of fusidic acid has been used on the world in recent ten years, has never been accepted in the United States. MRSA, with a long safety record has a great need for an oral MRSA antibiotic at the present time. In USA some drug companies worked to allow market exclusivity when this antibiotic is approved in the United States. A new dose arrangement that allowing fusidic acid to be used as monotherapy has been accepted, and it has been shown that fusidic acid resistance rates are reduced selectivity. ${ }^{11}$ Fusidic acid resistance rates were lowest in the United States, where fusidic acid is not used routinely in clinical treatment. Also resistance rates were low in Australia and Canada, where fusidic acid has been used as drug for more than twenty years, the data were not especially elevated in Australia and Canada. This observation is in accordance with other reports that also noted that emergence of fusidic acid resistance hasn't been rapid, although its clinical use and show that this antimicrobial agent still provides a potentially useful treatment option for infections caused by multidrug-resistant gram-positive isolates $(99.7 \%$ susceptibility among S.aureus strains), including MRSA strains. Fusidic acid resistance was viewed more frequently among MSSA isolates than among methicillin-resistant strains in the United States (0.6 and $0.1 \%$, respectively). Conversely, fusidic acid resistance was higher among MR-CNS isolates than among MS-CNS isolates (9.2 and 5.2\% for MRCNS and MS-CNS, respectively). Fusidic acid resistance rate has not evaluated for Canada and Australia because of the decreased numbers of strains included in study. Moreover, $36.0 \%$ of the fusidic acid resistant $S$.aureus strains has got also methicillin resistance. Occurrence rates of fusidic acid resistance among S.aureus $(0.3 \%)$ and CNS (7.2\%) isolates were notably lower in the United States than in other two countries analyzed. S.aureus strains with elevated fusidic acid MIC values were slightly more 
common in Australia than in Canada $(7.0 \%$ for both countries), but the CNS resistance rates were different, with resistance being more common in Canada (20.0\% versus $10.8 \%$ in Australia). ${ }^{2}$

In our country several studies have been done about fusidic acid resistance related to staphylococci (Table 4).

Table 4. Fusidic acid resistance rates of staphylococcal strains isolated in our country, in some studies.

\begin{tabular}{|c|c|c|c|c|c|}
\hline & Year & MSSA & MRSA & MS-CNS & MR-CNS \\
\hline Erdemoğlu et al. ${ }^{15}$ & 2000 & 3.2 & 7.7 & 10.8 & 14.9 \\
\hline Altun et al. ${ }^{16}$ & 2003 & 0 & 3 & 0 & 13 \\
\hline Şengöz et al. ${ }^{17}$ & 2004 & 1 & 9 & 21 & 33 \\
\hline Celen et al. ${ }^{18}$ & 2005 & 3 & 6 & 20 & 3 \\
\hline Nergiz et al. ${ }^{19}$ & 2007 & - & - & - & 28 \\
\hline Ekşi et al. ${ }^{20}$ & 2008 & 2.4 & 9.2 & - & - \\
\hline Mert Dinç et al. ${ }^{21}$ & 2009 & - & 1.4 & - & - \\
\hline Yaman et al. ${ }^{22}$ & 2010 & 4 & 6 & - & - \\
\hline Deveci et al. ${ }^{23}$ & 2011 & 4 & 1 & 14 & 8 \\
\hline
\end{tabular}

MSSA: methicillin sensitive S.aureus, MRSA: methicillin resistant S.aureus

MS-CNS: methicillin sensitive coagulase negative staphylococcus

MR-CNS: methicillin resistant coagulase negative staphylococcus

Keşli et al.12 reported that $63 \%$ of S.aureus and $50(66 \%)$ of CNS strains were methicillin resistant. Two $(7 \%)$ of MRSA strains, $1(6 \%)$ of MSSA strains, $16(32 \%)$ of MR-CNS strains and $3(12 \%)$ of MS-CNS strains were found to be resistant to fusidic acid. They indicated that fusidic has not to be excluded in preference of the antibiotic treatment of staphylococcal infections.

Kuzucu et al.13 investigated in vitro activity of fusidic acid in 112 MRSA and MR-CNS by disk diffusion and microdilution methods. $4 \%$ of MRSA and $27 \%$ MR-CNS were found to be resistant to fusidic acid.

In a study of Ulug et al.14 resistance to fusidic acid has been found as $4.3 \%$ in MSSA strains, $16.7 \%$ in MRSA strains, $0 \%$ in MS-CNS, $36 \%$ in MR-CNS, however in none of the strains vancomycin, and teicoplanin resistance have been observed.
In conclusion, the present study is in accordance with other reports that also noted that emergence of fusidic acid resistance has not been rapid, despite its clinical use, and demonstrates that this antimicrobial agent still provides a potentially useful treatment option for infections caused by multidrug-resistant gram-positive isolates, including MRSA strains.

\section{REFERENCES}

1. Castanheira M, Watters AA, Mendes RE, Farrell DJ, Jones $\mathrm{RN}$. Occurrence and molecular characterization of fusidic acid resistance mechanisms among Staphylococcus spp. from European countries (2008). J Antimicrob Chemother 2010;65(7):1353-8.

2. Castanheira M, Watters AA, Bell JM, Turnidge JD, Jones $\mathrm{RN}$. Fusidic acid resistance rates and prevalence of resistance mechanisms among Staphylococcus spp. isolated in North America and Australia, 2007-2008. Antimicrob Agents Chemother 2010;54(9):3614-7.

3. Bodley JW, Zieve FJ, Lin L, Zieve ST. Formation of the ribosome-G factor-GDP complex in the presence of fusidic acid. Biochem Biophys Res Commun 1969;37(3):437-43.

4. Gao YG, Selmer M, Dunham CM, Weixlbaumer A, Kelley AC, Ramakrishnan V. The structure of the ribosome with elongation factor $\mathrm{G}$ trapped in the posttranslocational state. Science 2009;326(5953):694-9.

5. Chen CM, Huang M, Chen HF, et al. Fusidic acid resistance among clinical isolates of methicillin-resistant Staphylococcus aureus in a Taiwanese hospital. BMC Microbiol 2011;11(1):98-102.

6. Clinical and Laboratory Standards Institute. Performance standards for antimicrobial susceptibility testing. Twentyfirst informational supplement. CLSI, M100-S21, 2011. Wayne, Pennsylvania, USA.

7. The European Committee on Antimicrobial Susceptibility Testing (EUCAST): Breakpoint tables for interpretations of MICs and zone diameters. EUCAST Clinical Breakpoint Table v. 1.1 2010-04-27. (http://www.eucast.org/fileadmin/ src/media/PDFs)

8. Farrell DJ, Castanheira M, Chopra I. Characterization of global patterns and the genetics of fusidic acid resistance. Clin Infect Dis 2011;52(Suppl 7):487-92.

9. McLaws FB, Larsen AR, Skov RL, Chopra I, O’Neill AJ. Distribution of fusidic acid resistance determinants in methicillin-resistant Staphylococcus aureus. Antimicrob Agents Chemother 2011;55(3):1173-6.

10. Chen HJ, Hung WC, Tseng SP, Tsai JC, Hsueh PR, Teng LJ. Fusidic Acid Resistance Determinants in Staphylococcus aureus Clinical Isolates. Antimicrob Agents Chemother 2010;54(12):4985-91.

11. Fernandes P, Pereira D. Efforts to support the development of fusidic acid in the United States. Clin Infect Dis 2011;52(Suppl 7):542-6.

12. Keşli R, Cander S, Çelebi S. Fusidic Acid Resistance of Methicillin Resistant and Sensitive Staphylococcus Strains Isolated From Clinical Specimens. Kocatepe T1p Dergisi 2004;5(2):33-6. 
13. Kuzucu Ç, Dalgalar M, Durmaz B. Metisiline dirençli Staphylococcus aureus ve koagülaz negatif stafilokoklarda fusidik asit duyarlılı̆̆1. ANKEM Derg 2003;17(1):7-9.

14. Uluğ M, Ayaz C, Celen MK. Fusidic acid's place in the treatment of chronic staphylococcal osteomyelitis. Anatol J Clin Invest 2009;3(3):222-6.

15. Erdemoğlu A, Özsoy MF, Emekdaş G, Öncül O, Pahsa A. The resistance of Staphylococci isolated from urine to fusidic acid and other antimicrobials. Türk Mikrobiol Cem Derg 2000;30(1):6-12.

16. Altun B, Kocagöz S, Hasçelik G, Uzun O, Akova M, Ünal S. Susceptibilities to fusidic acid and frequently used antibiotics of Staphylococcus strains isolated in various hospitals. Türk Mikrobiyol Cem Derg 2003;33(1):8-11.

17. Şengöz G, Yıldırım F, Kart-Yaşar K, Şengöz A, Nazlıcan O. Resistance of Staphylococcus strains against fusidic acid and other antibiotics. Ankem Derg 2004;18(1):105-8.

18. Çelen MK, Ayaz C, Özmen E, Geyik MF, Hoşoğlu S. Resistance to fucidic acid in clinical Staphylococcus aureus isolates. Klimik Derg 2005;18(1);114-6.
19. Nergiz S, Özekinci T, Gülhan B, Meşe S, Atmaca S. Resistance to fusidic acid in methicillin-resistant coagulase negative Staphylococci isolated from various clinical specimens. Ankem Derg 2007;21(2):228-31.

20. Ekşi F, Gayyurhan ED, Bayram A. Antimicrobial susceptibility of Staphylococcus aureus strains isolated in Gaziantep University Hospital. Ankem Derg 2008;22(2):203-8.

21. Mert Dinç B, Karabiber N, Aykut Arca E. Macrolide-Lincosamide-Streptogramin B (MLSB) resistance and fusidic acid susceptibility of methicillin resistant Staphylococcus aureus (MRSA) strains isolated from clinical samples. Türk Hijyen ve Deneysel Biyoloji Derg 2009;66(1):89-94.

22. Yaman G, Çıkman A, Berktaş M, Parlak M, Güdücüoğlu $\mathrm{H}$, Karahocagil MK. The MLSB, fusidic acid and various antibiotic resistance rates of nosocomial Staphylococcus aureus isolates. Ankem Derg 2010;24(1):130-5.

23. Deveci Ö, Kılıç D, Kaygusuz S, et al. Evaluation of resistance to fusidic acid in Staphylococci isolates. J Microbiol Infect Dis 2011;1(1):22-5. 